Clarke, C. A., Donohoe, W. T. A., McConnell, R. B., Woodrow, J. C., Finn, R., Krevans, J. R., Kulke, W., Lehane, D., and Sheppard, P. M. (1963). Brit. med. F., 1, 979.

Finn, R., McConnell, R. B., and Sheppard, P. M. (1958). Int. Arch. Allergy, 13, 380 .

Arch. Allergy, 13, 380. (1965). Lancet, 2, 343.

Collins, J. O., Sanger, R., Allen, F. H., and Race, R. R. (1950). Brit. med. F., 1, 1297. Creger, W. P., Choy, S. H., and Rantz, L. A. (1951). F. Immunol., 66,

de Dombal, F. T., Watts, J. M., Watkinson, G., and Goligher, J. C. (1965). Lancet, 2, 599.

Dodd, M. C., Bigley, Nancy J., Johnson, G. A., and McCluer, R. H. (1964). Nature (Lond.), 204, 549

Ducos, J. (1958). Rev. franc. Etud. clin. biol., 3, 1109.

Elliott, P. M. (1964). Programme, 7th Congress Australian Reg. Council of Royal College of Obstetricians and Gynaecologists, Surfer's Paradise, Queensland.

Engleson, G., and Zetterqvist, P. (1957). Arch. Dis. Childh., 32, 193

Epstein, W. V. (1965). Science, 148, 1591.

Fialkow, P. J. (1964). Lancet, 1, 474.

Uchida, I. A., Hecht, F., and Motulsky, A. G. (1965). Ibid., 2, 868. Finn, R. (1960). Ibid., 1, 526 .

Clarke, C. A., Donohoe, W. T. A., McConnell, R. B., Sheppard,

Freda, V. J. (1962). Amer. 7. Obstet. Gynec., 84, 1756.

Freda, and Gorman, J. G. (1962). Bull. Sloane Hosp. Wom. N.Y., 8, 147.

- and Pollack, W. (1964). Transfusion (Philad.), 4, 26.

Freed - (1965). Lancet, 2, 690 Freedberg, I. M., Hamolsky, M. W., and Freedberg, A. S. (1957). New
Engl. f. Med., 256, 505.

Good, W., Scott, J. S., Speight, R. B., and Wood, J. (1966). In preparation.

Goodhue, P. A., and Evans, T. S. (1963). Obstet. gynec. Surv., 18, 671.

Gorman, J. G., Freda, V. J., and Pollack, W. (1962). Proc. int. Congr. Haemat., 2, 545.

- (1965). Lancet, 2, 181

Harrington, W. J. (1957). F. chron. Dis., 6, 365.

Sprague, C. C., Minnich, V., Moore, C. V., Aulvin, R. C., and

Hawe, P., and Francis, H. H. (1962). Brit. med. 色, 2, 817.

Hench, P. S. (1938). Proc. Mayo Clin., 13, 161.

Kendail, E. C., Slocumb, C. H., and Polley, H. F. (1949). Ibid., 24,181 .

Heys, R. F. (1966). f. Obstet. Gynaec. Brit. Cwlth, 73, 205

Hutchison, J. H., Keay, A. J., and Kerr, M. M. (1962). Brit. med. f., 2, 436.

Irvine, W. J. (1964). Quart. F. exp. Physiol., 49, 324.

Jann, R. (1954). Arch. Gynäk., 184, 731.

Javett, S. N., Senior, B., Braudo, J. L., and Heymann, S. (1959). Pediatrics, 24, 65.

Jeffcoats, T. N. A., and Scott, J. S. (1959). Amer. F. Obstet. Gynec., 77, 475 .

John, A. H., and Duncan, A. S. (1964). \%. Obstet. Gynaec. Brit. Cwlth, 71, 61 .

Kadowaki, J., Thompson, R. I., Zuelzer, W. W., Woolley, P. V., Brough, A. J., and Gruber, D. (1965). Lancet, 2, 1152 .

Kaplan, D., and Diamond, H. (1965). Clin. Obstet. Gynec., 8, 286.

Keidan, S. E. (1955). Arch. Dis. Child., 30, 291.

Keynes, G. (1952). F. Obstet. Gynaec. Brit. Emp., 59, 173.

Kitselle, J. F. (1852). Fb. Kinderheilk., 18, 313.

Kleihauer, E., Braun, H., and Betke, K.' (1957). Klin. Wschr., 35, 637.

Kloosterman, G. J. (1947). Over de Polyletaliteit, in Verband met net Vlokkenstroma en de Rhesus Factor. Grafische Krunstinrichting Rotting. Hilversum.

Koerner, K. A. (1954). F. Pediat., 45, 464.

Kriss, J. P., Pleshakov, V., and Koblin, R. (1964). Clin. Res. Proc., 12, 116.

Kuhn, R., and Wiegandt, H. (1963). Chem. Ber., 96, 866.

Landucci-Rubini, L., and Battistini, A. (1962). Lattante, 33, 377.
Lawrence, R. D., and McCance, R. A. (1931). Arch. Dis. Childh., 6, 343.

Levine, P. (1943). f. Hered., 34, 71.

Liley, A. W. (1963). Brit. med. f., 2, 1107.

Lubchenco, L. O., Hansman, C., Dressler, M., and Boyd, E. (1963). Pediatrics, 32, 793.

McKenzie, J. M. (1958). Endocrinology, 62, 865.

- (1960). Physiol. Rev., 40, 398.

- (1961). F. clin. Endocr., 21, 635.

(1964). Ibid., 24, 660 .

McNall, P. G., and Jafarnia, M. R. (1965). Amer. F. Obstet. Gynec., 92, 518.

Mahoney, C. P., Pyne, G. E., Stamm, S. J., and Bakke, J. L. (1964). Amer. f. Dis. Child., 107, 516

Major, P. W., and Munro, D. S. (1960). F. Endocr., 20, XIX.

Medawar, P. B. (1960). The Future of Man, The Reith Lectures. Methuen, London.

Munro, D. S. (1959). F. Endocr., 19, 64.

Myant, N. B. (1958). Clin. Sci., 17, 75.

Nawrocka-Kańska, B. (1952). Pediat. pol., 27, 1067.

Nelson, J. H. (1965). Clin. Obstet. Gynec., 8, 263.

Osserman, K. E. (1960). In Medical, Surgical, and Gynecological Complications of Pregnancy, edited by A. F. Guttmacher and J. J. plications of Pregnancy, edited by A. F. Guttmach

- Kornfeld, P., Cohen, E., Genkins, G., Mendelow, H., Goldberg, H., Windsley, H. and Kaplan, L. I. (1958). Arch. intern. Med., 102, 72 .

Paatela, M. (1960). Ann. Paediat. Fenn., 6, 309.

Paterson, S. (1964). Med. f. Aust., 1, 275.

Pearson, H. A., Shulman, N. R., Marder, V. J., and Cone, T. E. (1964). Blood, 23, 154.

Peterson, O. H., and Larson, P. (1954). Obstet. and Gynec., 4, 454.

Peterson, R. R., and Young, W. C. (1952). Endocrinology, 50, 218.

Piper, J., and Rosen, J. (1954). Acta med. scand., 150, 215.

Purves, H. D., and Adams, D. D. (1961). In Advances in Thyroid Research, edited by R. V. Pitt-Rivers, p. 184. Pergamon Press, New York.

Ramsey, W. R. (1926). Trans. Amer. pediat. Soc., 38, 100.

Riley, I. D., and Sclare, G. (1957). Brit. med. F., 1, 979.

Robbins, J., and Rall, J. E. (1960). Physiol. Rev., 40, 415

Robson, H. N., and Davidson, L. S. P. (1950). Lancet, 2, 164.

Roitt, I. M., Doniach, D., Campbell, P. N., and Hudson R. V. (1956). Ibid., 2, 820.

Sahay, B. M., Blendis, L. M., and Greene, R. (1965). Brit. med. F., 762

Saxena, K. M., Crawford, J. D., and Talbot, N. B. (1964). Ibid., 2, 1153.

Sclare, G. (1960). Biol. Neonat. (Basel), 2, 132.

Scott, J. S. (1958). F. Obstet. Gynaec. Brit. Emp., 65, 689.

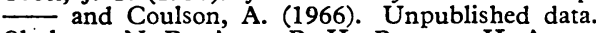

hulman, N. R., Aster, R. H., Pearson, H. A., and Miller, M. C. (1962), F. clin. Invest., 41, 1059.

Simpson, J. A. (1960). Scot. med. f., 5, 419.

- (1964). 7. Neurol. Neurosurg. Psychiat., 27, 485.

Sinclair, J. C., and Silverman, W. A. (1964). Lancet, 2, 1068.

Stern, G. M., Hall, J. M., and Robinson, D. C. (1964). Brit. med. f., 2 , 284.

Strandqvist, B. (1932). Acta paediat. (Uppsala), 13, 421.

Strickroot, F. L., Schaeffer, R. L., and Bergo, H. L. (1942). F. Amer. med. Ass., 120, 1207.

Sweetnam, W. P., and Sykes, C. G. W. (1962). Brit. med. f., 2, 671.

Tancer, M. L. (1960). Amer. F. Obstet. Gynec., 79, 148.

Taylor, A. I., and Polani, P. E. (1965). Lancet, 1, 1226.

van der Geld, H., Feltkamp, T. E. W., van Loghem, J. J., Oosterhuis, H. J. G. H., and Biemond, A. (1963). Ibid., 2, 373.

White, C. (1912). 7. Obstet. Gynec. Brit. Emp., 21, 231.

Williams, R. H., Kay, G. A., and Jandorf, B. J. (1944). F. clin. Invest., 23, 613 .

Woodrow, J. C., Clarke, C. A. Donohoe, W. T. A., Finn, R., McConnell, R. B., Sheppard, P. M., Lehane, D., Russell, S. H., Kulke, W., and Durkin, C. M. (1965). Brit. med. f., 1, 279.

Woodruff, P. (1940). Mod. F. Aust., 2, 190.

Zaidi, Z. H. (1965). Proc. roy. Soc. Med., 58, 390.

\title{
Intrahepatic Typhoid Carriers
}

\section{A. J. S. MCFADZEAN,* O.B.E., M.D., F.R.C.P., F.R.C.P.ED. ; G. B. ONG,† F.R.C.S., F.R.C.S.ED.}

Brit. med. F., 1966, 1, 1567-1571

Cholecystectomy was first advocated in the treatment of the biliary typhoid carrier by Dehler (1907). Whipple (1929) thought that it was successful in approximately $70 \%$ of cases, and this has been confirmed in other series reported from Europe and the United States of America (Browning, 1933; Humbert, 1959 ; Tynes and Utz, 1962). Wilson and Miles (1964), in explanation of the failure, stated: "It is not clear in what part of the intestinal tract the focus of infection persists, though there is reason to believe that it is in the biliary passages of the liver." Erlik and Reitler (1960) reported that bile from the hepatic ducts of four carriers contained Salmonella typhi, and that, following cholecystectomy, bile obtained through a T-tube inserted into the common bile-duct of three of these carriers contained the same organism. They concluded that their patients were intrahepatic carriers. Tynes and Utz (1962) included in their series two patients in whom 
culture of the liver biopsy specimen obtained at laparotomy yielded $S$. typhi.

The purpose of this communication is to report observations which indicate that among the Chinese in Hong Kong the intrahepatic carrier state is the rule, not the exception, and that the intrahepatic lesion may progress and the syndrome of recurrent pyogenic cholangitis (Cook, Hou, Ho, and McFadzean, 1954) develop.

\section{Effect of Cholecystectomy}

In 1949 eight southern Chinese carriers of S. typhi were subjected to cholecystectomy. The first two operations resulted from a suspicion that the gall-bladder was responsible for the carrier state. The operations on the remaining six patients were undertaken to determine whether in Hong Kong cholecystectomy was of value in the eradication of the carrier state. Certain details of the carriers are set out in the Table. Their ages ranged from 23 to 41 years, and four were males. Five had recovered from a known attack of typhoid fever. Their remaining three one had a history of prolonged fever five years before discovery of the carrier state, another claimed never to have been ill, and the eighth gave a five-year history of irregular attacks of fever, which latterly were accompanied by right upper abdominal discomfort and dark urine. These attacks did not prevent his working.

$S$. typhi was isolated on numerous occasions either from the faeces or from fluid aspirated from the duodenum through a duodenal tube. Oral cholecystography showed a normalfunctioning gall-bladder in seven instances. The gall-bladder of the eighth patient was regarded, after repeated examination, as not functioning.

At operation on each of the seven patients with normally functioning gall-bladders the gall-bladder and extrahepatic ducts appeared normal. In four instances the surface of the liver showed the changes encountered in infection with Clonorchis sinensis (Hou, 1955), and in these four only ova of C. sinensis were found on microscopical examination of the stools. Five of the gall-bladders were examined histologically and no significant abnormality was detected.

The gall-bladder in Case 8, regarded radiologically as not functioning, was dilated, as were also the extrahepatic ducts. When the common duct was opened it was found to contain a cylindrical stone, $2 \mathrm{~cm}$. in length and in diameter, and much biliary mud. The stone and mud were removed and a T-tube was inserted into the duct. An incision over a hard mass felt in the periphery of the right lobe showed the mass to be due to a stone, which was removed. Ova of $C$. sinensis were found on microscopical examination of the bile obtained from the T-tube. A post-operative cholangiogram showed a generalized dilatation of the intrahepatic and extrahepatic bileducts. Negative shadows, restricted to a segment of the right lobe, were consistent with the presence of intrahepatic calculi.
Histological examination of the gall-bladder revealed chronic inflammatory changes which were restricted to the mucosa. There was no evidence of fibrosis.

The stones removed from the common bile-duct and from the liver were washed and then immersed in a solution of mercuric chloride for 60 minutes. After further washing in sterile water they were cut in half, and cultures of scrapings from the centres of the stones yielded $S$. typhi.

\section{Results}

In each instance fluid was aspirated from the duodenum at intervals up to eight weeks after the operation, and cultures of all specimens yielded S. typhi. The T-tube in the eighth patient was left in position for seven weeks, and $S$. typhi was isolated on culture of the bile obtained therefrom at intervals, including the day before removal of the tube.

The patients have been followed up for 2 to 16 years after operation (see Table), and during this period in each instance cultures of fluid aspirated from the duodenum continued to yield $S$. typhi.

One of the five patients found to be a carrier following recovery from a known attack of typhoid (Case 4) was readmitted to hospital seven years after cholecystectomy with the fully developed clinical picture of recurrent pyogenic cholangitis. There was a history of similar attacks over the preceding two years. At operation the extrahepatic ducts were found to be widely dilated but did not contain stones. A T-tube was inserted and a post-operative cholangiogram confirmed the absence of stones from the extrahepatic ducts. The intrahepatic ducts were shown also to be widely dilated, and there were numerous negative shadows consistent with intrahepatic stones. Culture of the bile obtained from the T-tube yielded S. typhi.

One patient (Case 5) died from an unrelated illness seven years after cholecystectomy. A cholangiogram of the liver, which was excised at necropsy, showed dilatation and crowding together of the smaller bile-ducts in a segment of the left lobe. The dilatation of small ducts and loss of surrounding parenchyma were confirmed on slicing the liver, and the culture of fluid within the dilated ducts yielded S. typhi. The histological appearances were in no way distinct from those described by Cook et al. (1954) as occurring in the stage of remission in recurrent pyogenic cholangitis.

C. Forrest (personal communication, 1965) has independently confirmed the failure of cholecystectomy to eradicate the carrier state in Chinese in Hong Kong.

\section{Salmonella as a Cause of Pyogenic Cholangitis}

In a paper entitled "Common Duct Stones of Liver Origin" Digby (1930) first drew attention to the occurrence among the

Certain Details of 8 Typhoid Carriers on Whom Cholecystectomy was Performed

\begin{tabular}{|c|c|c|c|c|c|c|c|}
\hline $\begin{array}{l}\text { Case } \\
\text { No. }\end{array}$ & Sex & $\begin{array}{c}\text { Age } \\
\text { at } \\
\text { Diagnosis }\end{array}$ & Relevant Previous History & $\begin{array}{l}\text { Evidence of } \\
\text { Infection by } \\
\text { C. sinensis }\end{array}$ & $\begin{array}{c}\text { Years } \\
\text { of } \\
\text { Observation }\end{array}$ & $\begin{array}{c}\text { Last } \\
\text { Cholangiography } \\
\text { (Method-year) }\end{array}$ & Remarks \\
\hline 1 & $\mathrm{~F}$ & 31 & Typhoid (S. typhi isolated) & Absent & 5 & - & $\begin{array}{l}\text { Symptomless excretion for } 5 \text { years. } \\
\text { Contact lost }\end{array}$ \\
\hline 2 & $\underset{\mathrm{F}}{\mathrm{M}}$ & $\begin{array}{l}23 \\
30\end{array}$ & ", & $\begin{array}{c}\text { Present } \\
\text {, }\end{array}$ & $\begin{array}{l}16 \\
13\end{array}$ & $\begin{array}{l}\text { Normal (intravenous -1964) } \\
\text { Normal (1961) }\end{array}$ & $\begin{array}{l}\text { Symptomless excretion for } 16 \text { years } \\
\text { Symptomless excretion for } 13 \text { years. } \\
\text { Contact lost }\end{array}$ \\
\hline 4 & $\mathbf{M}$ & 28 & " & " & 9 & $\begin{array}{l}\text { Generalized dilatation of intra- and } \\
\text { extrahepatic ducts, intrahepatic } \\
\text { stones (Post-operative-1956) }\end{array}$ & $\begin{array}{l}\text { Symptomless excretion for } 5 \text { years. } \\
\text { Thereafter symptoms of recurrent } \\
\text { pyogenic cholangitis developed. } \\
\text { Contact lost }\end{array}$ \\
\hline 5 & $\mathbf{M}$ & 41 & $"$ & Absent & 7 & $\begin{array}{l}\text { Localized dilatation of intrahepatic } \\
\text { biliary tree (Necropsy-1956) }\end{array}$ & $\begin{array}{l}\text { Symptomless excretion for } 7 \text { years } \\
\text { until death from unrelated illness }\end{array}$ \\
\hline $\begin{array}{l}6 \\
7\end{array}$ & $\underset{\mathrm{F}}{\mathrm{F}}$ & $\begin{array}{l}32 \\
33\end{array}$ & $\begin{array}{l}\text { Prolonged fever } 5 \text { years before } \\
\text { Nil }\end{array}$ & $\begin{array}{l}\text { Present } \\
\text { Absent }\end{array}$ & $\begin{array}{r}16 \\
2\end{array}$ & Normal (Intravenous-1963) & $\begin{array}{l}\text { Symptomless excretion for } 16 \text { years } \\
\text { Symptomless excretion for } 2 \text { years. } \\
\text { Contact lost }\end{array}$ \\
\hline 8 & $M$ & 37 & $\begin{array}{l}\text { Recurrent fever for } 5 \text { years. } \\
\text { Symptoms consistent with } \\
\text { pyogenic cholangitis }\end{array}$ & Present & & $\begin{array}{l}\text { Generalized dilatation of intra- and } \\
\text { extrahepatic bile-ducts. Calculi } \\
\text { in intra- and extrahepatic ducts. } \\
\text { (Operation-1949) }\end{array}$ & $\begin{array}{l}\text { Recurrent pyogenic cholangitis at } \\
\text { time of diagnosis of carrier state. } \\
\text { Contact lost }\end{array}$ \\
\hline
\end{tabular}


Chinese in Hong Kong of a syndrome to which Cook et al. (1954) gave the name " recurrent pyogenic cholangitis," for they found the syndrome basically to be a recurring infection of the biliary tree with pyogenic organisms, notably Escherichia coli. When fully developed the syndrome, which has an equal sex incidence, consists of recurrent attacks of fever greatly varying in duration and severity, of right upper abdominal pain, either lancinating or colicky in character, and of jaundice. The liver and gall-bladder are commonly palpably enlarged, and there is a variable polymorphonuclear leucocytosis. The alkaline phosphatase is elevated, and in the presence of jaundice this rise is greater than that to be expected from the degree of jaundice. Invariably there is biochemical evidence of parenchymatous damage. In most instances the fully developed syndrome is preceded by perplexing attacks of fever, and the earliest localizing symptom is the occurrence of vague discomfort over the liver. Stones and biliary mud form in the intrahepatic and extrahepatic ducts, and, less frequently, in the gallbladder, but it should be noted that the disease may progress to a fatal issue without their formation. The stones are almost invariably pigment stones-the earthy stones of Aschoff (1924).

The earliest lesion detected on post-operative cholarigiography is a dilatation and crowding together of the smaller ducts in one segment of the liver. The sequence of events must be a matter of surmise, but clinical observation and a study of material obtained at necropsy has led to the postulation that infection settles in the parenchyma and ducts of a segment of the liver. In some instances the lesion does not progress, and these patients remain symptomless excreters of $E$. coli in the bile. In other instances a descending infection of the biliary system follows. Once established there are periods of exacerbation and remission. During the former, obstruction of the larger ducts into which the infected segment drains occurs, and this results in back-flow infection of hitherto unaffected ducts. Ultimately the common duct is involved, and obstruction thereto is produced either by spasm of the sphincter or by stones. In this event back-flow infection involves the gall-bladder and the total biliary tree.

Cook et al. (1954) presented evidence that infection of the bile-ducts by $C$. sinensis might play a part in predisposing to the initial infection, but for a variety of reasons they concluded that clonorchiasis could not be the sole cause, a conclusion also reached on different evidence by Ong (1962). This conclusion was supported by the microscopical study of sections of stones from the intrahepatic and extrahepatic ducts of 42 patients with recurrent pyogenic cholangitis reported by Teoh (1963). He found that the stones incorporated parasitic remnants in the nucleus in 24 instances but in 16 the parasite was Ascaris lumbricoides; in the remaining eight it was C. sinensis.

The evidence linking clonorchiasis with such infection was strengthened by the report by McFadzean and Yeung (1965) of a series of patients with a fulminating pyogenic infection of the entire biliary tree invariably associated with massive infection by clonorchis and presenting with hypoglycaemia.

In order to determine how frequently salmonellae were a cause of recurrent pyogenic cholangitis, 100 consecutive patients suffering from this disease were investigated at operation. Specimens of bile were aspirated, prior to opening the common duct, from the hepatic duct by needle and syringe and cultured.

\section{Results}

In four instances salmonellae were isolated in pure culture. The species were $S$. typhi, $S$. sendai, and, in two instances, $S$. paratyphi $A$. A fifth specimen yielded a growth of both $S$. typhi and $E$. coli. Three of the patients were females. Only one patient had a previous history of typhoid. Ova of $C$. sinensis were found in three instances on microscopical examination of the bile collected from the T-tube subsequently inserted into the common bile-duct. The history and the clinical, laboratory, and operative findings in these five patients were in no way different from those encountered in patients in whom the causative organism was $E$. coli, which was isolated in pure culture in 84 instances. It should be noted that the acute exacerbations of infection which had resulted in the admission of these five patients to hospital rapidly responded to chloramphenicol.

C. T. Huang (personal communication, 1965) has made available to us the results of routine bacteriological examination of 636 specimens of bile, the overwhelming majority of which were obtained at operation on patients with recurrent pyogenic cholangitis. In 20 instances salmonellae were isolated in pure culture. The species encountered were $S$. typhi (10), $S$. paratyphi $A(5), S$. sendai (2), S. blegden (2), and $S$. paratyphi $C$ (1). In addition, in two instances culture yielded a mixed growth of $S$, typhi and $E$. coli.

\section{Frequency of Development of Recurrent Pyogenic Cholangitis in the Typhoid Carrier State}

Twenty-three symptomless excreters of salmonellae, assumed to be intrahepatic carriers, were observed for from 4 to 14 (mean, 7.2 ; S.D., 3.2) years. Their ages ranged from 19 to 36 years, and 12 of the 23 were males. Ova of $C$. sinensis were found on microscopical examination of fluid aspirated from the duodenum in 12. Repeated examinations were negative in the remaining 11 .

\section{Results}

Two of the carriers developed the clinical picture of recurrent pyogenic cholangitis five and six years respectively after becoming symptomless excreters. The diagnosis in each instance was confirmed at operation, when the intrahepatic infection was also confirmed on culture of bile obtained by hepatic puncture. Cholecystectomy was performed in another hospital on a third patient, who, after the operation, continued to excrete salmonellae.

\section{Treatment}

A variety of antibiotics and sulphonamides available prior to the introduction of ampicillin have been employed alone and in combination in an attempt to eradicate the infection in symptomless excreters, cholecystectomized symptomless excreters, and excreters suffering from recurrent pyogenic cholangitis. These last coincidentally underwent surgical treatment. The agents used included sulphaguanidine (Loewenthal and Corfield, 1943), penicillin in varying dosage up to 50 mega units daily by intravenous drip, with and without probenicid $1.5 \mathrm{~g}$. twice a day (Parker, Fitzgerald, Perry, and Woodward, 1953), chloramphenicol, and tetracycline (Humbert, 1959). In none was the infection eradicated. In each instance culture of fluid aspirated from the duodenum one month after completion of the course yielded a growth of the species of salmonella isolated prior to treatment.

Reports of the successful treatment of salmonella carriers by ampicillin (Trafford, MacLaren, Lillicrap, Barnes, Houston, and Knox, 1962; Tynes and Utz, 1962; Bullock, 1963 ; Christie, 1964) led us to use this semisynthetic agent on two symptomless excreters with normal intravenous cholangiograms (group A), two symptomless cholecystectomized excreters (Cases 2 and 6, see Table, group B), and four patients with recurrent pyogenic cholangitis who had been treated surgically and who since operation had been symptomless excreters (group C). S. typhi was the species isolated in the four patients in groups A and B and in two of the four patients 
in group C. $S$. sendai and $S$. paratyphi $A$ were the species isolated in the two remaining patients in group $C$.

For the first two weeks ampicillin, $1 \mathrm{~g}$. six-hourly, was given by mouth. Thereafter it was reduced to $1 \mathrm{~g}$. three times a day. Throughout the course of treatment probenecid, $1 \mathrm{~g}$. twice a day, was also taken.

\section{Results}

All save one, the patient in group C excreting $S$. paratyphi $A$, were treated for six months. The exception apparently developed an erythematous rash, possibly with scattered petechiae, four months after the beginning of treatment, which he promptly discontinued. He was not seen again until two months later.

During the course of treatment at irregular intervals duodenal fluid was aspirated and cultured. From none of these specimens were salmonellae isolated. But in every instance similar specimens obtained one month after completion of the full course of treatment of six months, or, in the case of the absconder, two months after treatment for four months, yielded a growth of the species of salmonella isolated before treatment.

\section{Discussion}

The evidence presented is consistent with the biliary typhoid carrier state in Hong Kong Chinese being due to a reservoir of infection within the liver from which salmonellae are discharged into the bile. The spectrum of clinical presentations differs in no way from that encountered in pyogenic cholangitis due to $E$. coli, and ranges from symptomless excretion from a focus restricted to a small segment of the liver to a recurring infection involving the entire biliary system, associated with obstruction to the common bile-duct, and, commonly, with the formation of calculi in the intrahepatic and extrahepatic biliary tree. As in $E$. coli infection, the sex incidence is equal. Only by isolation of the responsible organism on culture of the bile can pyogenic cholangitis due to salmonella be distinguished from that due to $E$. coli.

The carrier state in Hong Kong not only differs in the locale of the reservoir maintaining the infection but also in having an equal sex incidence. In Europe and in the United States there is a higher incidence among women. For example, the ratio of females to males in the series reported by Tynes and Utz (1962) was 3:1. Vogelsang (1929) and Ames and Robins (1943) have pointed out that there is a striking similarity, so far as age and sex are concerned, between the incidence of the carrier state and that of gall-stones. This suggests the possibility that chronic cholecystitis predisposes to the carrier state. The chronic cholecystitis of Europe and the United States is rarely encountered among Hong Kong Chinese, and this rarity may account for the seeming absence of the gallbladder carrier. Impressively the carrier state here reported follows the pattern of the local commonplace disease of the biliary system, pyogenic cholangitis, a disease in which the gall-bladder is more sinned against than sinning.

Though the period of observation is restricted, it would appear that the majority of carriers remain symptomless excreters. Only a minority progress to the fully developed syndrome of recurrent pyogenic cholangitis. We have no knowledge of the factor or factors determining this progression save that it does not seem to be a function of the duration of the carrier state. If it is assumed that the progression of the disease stems from the development of stones within the biliary tree then these would appear to develop by chance. According to Rains (1962), infection plays its part in the formation of calculi by causing stasis and providing the proteinous milieu in which stones will grow.

The factors responsible for the persistence within the liver of salmonellae have not been determined. Recurrent pyogenic cholangitis would appear to be the sequel and not the cause of the carrier state. This is evidenced by the isolation of salmonellae in pure culture in the majority of patients with salmonella pyogenic cholangitis and by the observed development of this syndrome in previously symptomless excreters. The sequence of events in the exceptional mixed infections is not known. We have no evidence that migrating roundworms play a part, as they seem to do, in bile-duct infection due to $E$. coli, but we have not excluded this possibility. The incidence of clonorchis infection in the three groups of salmonella excreters is significantly higher than in the general population $(P<0.001)$.

As in pyogenic cholangitis due to $E$. coli, the flukes, which produce obstruction to intrahepatic ducts (Hou, 1955), may well have a part to play in some instances in determining the persistence of the salmonellae within the bile-ducts. Such an infection cannot account for all. There was no evidence of infection with flukes in $44 \%$ of the excreters. Further, while the incidence of typhoid fever and that of the carrier state are equal in both sexes, the incidence of the fluke infection is higher in males, the ratio of infected males to females being 1.5:1 (C. T. Huang, personal communication, 1965). Additionally, the intrahepatic carrier is known to occur in areas where infection with this fluke does not exist. Intrahepatic carriers have been reported by Erlik and Reitler (1960) and by Tynes and Utz (1962), and the existence of such may be inferred from reports from Europe and the United States of America on the failure of cholecystectomy alone to eradicate the carrier state in from 25 to $30 \%$ of cases (Whipple, 1929 ; Browning, 1933 ; Humbert, 1959 ; Tynes and Utz, 1962).

The principles of treatment of recurrent pyogenic cholangitis consist in the control of the acute exacerbations of the infection, the removal of accessible stones from the biliary tract, and the establishment of internal drainage of the common bile-duct (Ong, 1962). This latter, which has as its object the prevention of recurrence of obstruction to the common bile-duct, may be achieved either by a transduodenal choledochostomy fashioned in such a way as to prevent reflux of duodenal contents into the biliary tract, or by a choledochojejunostomy with a Rouxen-Y loop. Experience has shown that the latter is the better operation. Segmental resection of the liver thus far has been restricted to segments in which the disease was far advanced, but we hold it to have a place when it can be demonstrated that the lesion, independent of the degree of its development, is localized.

Control of the acute exacerbation of $E$. coli infection in the main can readily be achieved. But Cook et al. (1954), employing both locally and systemically the chemotherapeutic agents and antibiotics then available, found that it was impossible to eradicate the infection. During the period of T-tube drainage of the common bile-duct, a maximum of 12 weeks, the causal organism persisted in the bile. In other words, after treatment their patients became for the time being symptomless excreters of $E$. coli. These findings have been confirmed. Thin plastic tubes have been inserted at operation into the right and left hepatic ducts through the liver and the proximal ends brought out through the abdominal wall. This permitted both local instillation of antibiotics and culture of aspirated bile over a longer period of treatment with a wider range of antibiotics than that available to Cook et al. (1954).

The same sorry story is here repeated with salmonella infections of the biliary tree. Acute exacerbations of infection have readily been brought under control by chloramphenicol, but, independent of whether the picture was one of symptomless excretion or of overt pyogenic cholangitis, it has proved impossible to eradicate the infection. The failure of ampicillin so to do, in view of reports of its successful use in curing gall-bladder carriers, is disappointing. Erlik and Reitler (1960) have reported the successful treatment of intrahepatic carriers 
by a combination of cholecystectomy, T-tube drainage of the common bile-duct, and irrigation of the ducts with a solution of oxytetracycline. In view of our complete failure to eradicate E. coli infections by a similar technique the method has not been employed.

The factors which militate against eradication of the infection are probably those also operative in $E$. coli infections. In the early lesion the parenchyma of the affected segment is so grossly disrupted by chronic inflammatory tissue that it is doubtful if bile is secreted into the dilated ducts. Antibiotics excreted in the bile will therefore be ineffective. Further, the replacing tissue in the quiescent phase is relatively avascular and penetration to the foci of infection therein will be impeded. Once stones form in the biliary tree another factor in the maintenance of the infection is added. Whipple (1929) claimed that "the presence of stones, porous and pervious to typhoid bacilli ... reinfects the fresh incoming bile." Tynes and Utz (1962), in a series of elegant experiments, have obtained evidence that this may well be the case.

\section{Summary}

The typhoid-carrier state among the Chinese in Hong Kong differs from that reported in Europe and the U.S.A. in that there is an equal sex incidence and cholecystectomy fails to eradicate the infection. Evidence is presented which is consistent with the carrier state being maintained by a focus of infection within the liver, a focus which is indistinguishable from the early lesion encountered in pyogenic cholangitis due to $E$. coli, the common disease of the biliary tract in Hong Kong. It is concluded that the absence of the gall-bladder carrier may be attributable to the rarity of chronic cholecystitis.

The factors responsible for the persistence of the salmonellae within the liver have not been determined. In view of a significantly higher incidence in typhoid carriers of infection of the bile-ducts with a liver fluke, $C$. sinensis, it is concluded that this infection may be a factor, though it cannot be the only one.
While the majority of carriers remain symptomless excreters, in a minority the infection extends, and the syndrome of recurrent pyogenic cholangitis which develops can be distinguished from that due to $E$. coli only by bacteriological investigation. It would appear that approximately $5 \%$ of cases of recurrent pyogenic cholangitis are due to salmonellae.

Sulphonamides and a variety of antibiotics have been used in an attempt to eradicate the infection, but to no avail. A six-months course of ampicillin and probenecid similarly failed to eradicate the infection in symptomless carriers, symptomless cholecystectomized carriers, and carriers with recurrent pyogenic cholangitis who had been treated surgically.

The public health implications of the reported findings are obvious. These are not restricted to Hong Kong. For example, there are some thousands of Chinese, recent emigrants from Hong Kong, employed in restaurants in the United Kingdom.

\section{REFERENCES}

Ames, W. R., and Robins, M. (1943). Amer. f. publ. Hlth, 33, 221. Aschoff, L. (1924). Lectures on Pathology. Hoeber, New York

Browning, C. H. (1933). Spec. Rep. Ser. med. Res. Coun. (Lond.), No. 179 .

Bullock, W. E. (1963). Amer. F. med. Sci., 246, 42.

Christie, A. B. (1964). Postgrad. med. F., Suppl. to vol. 40, p. 84. Cook, J., Hou, P. C., Ho, H. C., and McFadzean, A J. S. (1954). Brit f. Surg., 42, 188.

Dehler, H. (1907). Münch. med. Wschr., 54, 779.

Digby, K. H. (1930). Brit. F. Surg., 17, 578.

Erlik, D., and Reitler, R. (1960). Lancet, 1, 1216.

Hou, P. C. (1955). F. Path. Bact., 70, 53.

Humbert, R. (1959). Dtsch. med.'Wschr., 84, 742.

Loewenthal, H., and Corfield, W. F (1943), 742.

Loewenthal, H., and Corfield, W. F. (1943). Brit. med. f., 2, 105 Fadzean, A. J. S., and Yeung, R. T. T. (1965). Trans. roy. Soc. trop. Med. Hyg., 59, 179

Ong, G. B. (1962). Arch. Surg., 84, 199.

Parker, R. T., Fitzgerald, J. C., Perry, H. D., and Woodward, T. B. (1953). भ. clin. Invest., 32, 593.

Rains, A. J. H. (1962). Brit. med. F., 2, 685

Teoh, T. B. (1963). 7. Path. Bact. 86, i23

Trafford, J. A. P., MacLaren, D. M., Lillicrap, D. A., Barnes, R. D. S. Houston, J. C., and Knox, R. (1962). Lancet, 1, 987.

Tynes, B. S., and Utz, J. P. (1962). Ann. intern. Med., 57, 871

Vogelsang, T. M. (1929). Med. Rev. (Bergen), 46, 1.

Whipple, A. O. (1929). Ann. Surg., 90, 631.

Wilson, G. S., and Miles, A. A. (1964). Topley and Wilson's Principles of Bacteriology and Immunity, 5th ed. Arnold, London.

\title{
Placental Localization by Thermography
}

\author{
K. G. MILLAR,* M.B., CH.B.
}

Brit. med. F., 1966, 1, 1571-1574

An accurate method of locating the placental site without exposing the mother and foetus to irradiation would be a major advance in obstetrics. Thermography-the pictorial representation of body-heat patterns-has been claimed to be such a method (Young, 1964 ; Birnbaum and Kliot, 1965). The present study was undertaken to investigate this application of thermography.

\section{Method}

Theory.-Thermography depicts superficial heat patterns and has been used to investigate breast neoplasms (Lawson, 1956 ; Lloyd Williams, K., Lloyd Williams, F., and Handley, 1960, 1961), vascular occlusions (Barnes, 1963), rheumatoid arthritis, and burns. Placental localization by this method is based on the premise, as yet unproved, that the placenta, being

* Senior House Officer, the Queen Mother's Hospital, Glasgow. an arteriovenous "fistula," has a temperature higher than its immediate environment, and that the heat from this area is transmitted through the adjacent anterior abdominal wall to produce a characteristic pattern of heat emission on its surface.

Apparatus.-The high-speed infra-red detection apparatus (Pyroscan) (Fig. 1) was supplied by S. Smith \& Sons (England) Ltd., and has been described in detail by Cade (1964). Briefly, the machine consists of a silvered mirror which scans the patient's abdomen horizontally and vertically. The heat image obtained is transmitted via a mirror system to an indium antimonide photoconductive cell, operating at $-200^{\circ}$ C., where it is converted into a minute electrical impulse. This signal is amplified about a million times and is then "fed" to an electrode over which electrosensitive paper passes. When the signal is "cold" a black image appears on the paper, when "hot" a white image is produced, and between the two are numerous shades of grey. A switch, incorporated into the machine after the initial series was completed, enables the 